International Journal of Agriculture, Environment and Bioresearch

Vol. 4, No. 03; 2019

ISSN: $2456-8643$

\title{
EFFECT OF AZOTOBACTER AND ANTIBIOTIC ON SOIL NITROGEN AND RICE SEEDLING GROWTH IN SALINE SOIL
}

\author{
Reginawanti Hindersah, Vidianita Putri, Oviyanti Mulyani and Tualar Simarmata \\ Universitas Padjadjaran, Faculty of Agriculture Jalan Raya Bandung-Sumedang Km. 21, Jatinangor, Sumedang \\ 45363, Indonesia
}

http://doi.org/10.35410/IJAEB.2019.112118

\begin{abstract}
Saline soil in general has low nitrogen $(\mathrm{N})$ availability and restricted $\mathrm{N}$ uptake. Application of manure and nitrogen fixing bacteria (NFB) in addition to inorganic fertilizer are needed but manure amendment on soil will contribute to increase antibiotic residue in soil. A pot experiment has been conducted to verify the effect of antibiotic-resistance NFB Azotobacter on nitrogen availability and growth of rice seedling in saline soil contaminated with tetracycline and ampicillin. Green house experiment was arranged in factorial Randomized Block Design to examine four concentrations of Azotobacter sp. liquid culture and two kind of generic antibiotic. The first factor was without and with 106 , 107, and 108 CFU g-1 of Azotobacter inoculation, and the second one were antibiotic treatment consisted of tetracycline and ampicillin applied at 1 $\mathrm{mg} / \mathrm{kg}$. The results showed that neither Azotobacter nor antibiotic affected plant height, soil $\mathrm{pH}$ and EC, as well as Azotobacter population in rice rhizosphere. The interaction effect on both treatment was significant on total nitrogen in soil. This research suggested that Azotobacter maintained soil $\mathrm{N}$ when inoculated to soil up to $106 \mathrm{CFU} / \mathrm{g}$ and $108 \mathrm{CFU} / \mathrm{g}$ irrespective of antibiotic contamination but the bacteria had not yet affect growth of rice seedling in high sodium soil.
\end{abstract}

Keywords: Nitrogen, Azotobacter, Sodium, Rice Seedling, Soil Electrical conductivity

\section{INTRODUCTION}

To increase rice production, suboptimal land area of saline soil in Indonesia is put in use. Saline soil contains excessive soluble salts mainly sodium in soil solution and cause high osmotic pressure [1]. Salinity influence nitrogen transformation in soil resulting in reduced nitrogen availability for roots uptake. Soil nitrification at EC of $20 \mathrm{dS} / \mathrm{m}$ was inhibited up to $75 \%$ and $83 \%$ when ammonium sulfate and urea were applied respectively [2]. Medium to high salinity promote nitrite accumulate due to suppression on second step of nitrification, leaving more ammonium accumulation in soil [3].

High osmotic pressure and low available nitrogen in saline soil are unsuitable for plant growth. The limitation of $\mathrm{N}$ in saline soils could be overcome, among others, by application of organic matter and nitrogen fixing bacteria. Amendment of $20 \mathrm{t} / \mathrm{ha}$ of manure on saline soil with EC 4.1 
$\mathrm{dS} / \mathrm{m}$ significantly increased growth and dry matter weight of Sesbania grandiflora [4]. Organic matter widely used in rice production in Indonesia is chicken manure which contain some antibiotic residue [5]. and contributed to the antibiotic resistance bacteria in soil [6, 7]. Widely used antibiotic in poultry farming in Indonesia was tetracycline and ampicillin.

Biofertilizers are alternative to chemical fertilizers for nutrient source in food crops production. Azotobacter sp. is a prominent nitrogen fixing bacteria which widely used as biofertilizer. The bacteria fix nitrogen and produce phytohormones indole acetic acid (IAA) and gibberellins which contribute to plant growth [8,9]. Azotobacter inoculation combined with $25 \%-100 \%$ urea improved rice growth [10]. Azotobacter is heterotrophic bacteria that utilize organic matter as carbon and energy source. Regarding the presence of antibiotics in manure, the utilization of Azotobacter as biofertilizer for rice production in saline soils requires Azotobacter which is resistant to antibiotics and at the same time to high salinity. Salt-tolerant Azotobacter was reported elsewhere. Azotobacter salinestris fixed nitrogen in the presence of 1.0 to $1.5 \%$ Sodium Chloride $(\mathrm{NaCl})$ and the cells grew well in marine broth alone [11]. Certain isolates of Azotobacter were reported showed a tolerance for $\mathrm{NaCl}$ up to $10 \%[12,13]$. In the presence of $0.3 \mathrm{M}$ of salt, Azotobacter $\mathrm{H} 12$ enhanced nitrogen fixation, and some isolates increased IAA production in media with $0.3 \%$ salt although their growth was restricted [14].

Research of antibiotic-resistance Azotobacter on rice grown in saline soil have not been done intensively in Indonesia. Rice is a major staple food in Indonesia and their tolerance to high salt concentration will be important when rice production carried out in the coastal area dominated by saline soil. Salt-tolerant characteristics was depend on rice variety although it was reported that rice was susceptible on salt [15]. The objective of this research was to verify the effect of antibiotic-resistance NFB Azotobacter on nitrogen availability and growth of rice seedling in saline soil contaminated with tetracycline and ampicillin.

\section{MAterial AND Method}

Green house experiment was carried out in April to Mei 2018 at Faculty of Agriculture Universitas Padjadjaran, Jatinangor Campus, West Java located in tropic at the altitude of 625 above sea level. Azotobacter $\mathrm{sp}$. $\mathrm{K} 4$ which was resistance to $50 \mathrm{mg} / \mathrm{L}$ tetracycline and ampicillin belongs to Laboratory of Soil Biology Faculty of Agriculture. Liquid inoculants was prepared di $\mathrm{N}$-free Ashby medium; a total of 5\% Azotobacter pure culture inoculated to sterilized liquid media and incubated on $115 \mathrm{rpm}$ shaker for 72 hours at room temperature $\left(24-27^{\circ} \mathrm{C}\right)$.

The soil was saline clay soil collected from Karawang District, West Java; soil characters were slightly acid ( $\mathrm{pH} 6.05$ ); low in C-organic (1.24\%), total nitrogen (0.19\%) and ratio $\mathrm{C}$ to $\mathrm{N}(6.5)$; very low in $\mathrm{P}_{2} \mathrm{O}_{5}$ and $\mathrm{K}_{2} \mathrm{O}(0.14 \mathrm{mg} / 100 \mathrm{~g}$ and $9.41 \mathrm{mg} / 100 \mathrm{~g}$ respectively). with very high exchangeable sodium $(2.39 \mathrm{cmol} / \mathrm{kg})$. Electrical conductivity (EC) of soil was high $(1.8 \mathrm{dS} / \mathrm{m})$; Clay soil with EC $1 \mathrm{dS} / \mathrm{m}-2 \mathrm{dS} / \mathrm{m}$ determined by the $1: 5$ dilution method is classified as a high salinity soil [16]. Experiment was carried out by used of salinity stress resistant rice variety namely Inpari-34 produced by Food Crops Development and Research Centre of Indonesian Ministry of Agriculture. 
The experimental design was Factorial Completely Randomized Block Design to test Azotobacter and antibiotic treatment factor. Azotobacter treatment consisted of Azotobacter inoculation to soil up to $10^{6}, 10^{7}$ and $10^{8}$ Colony Forming Unit (CFU)/g before rice seedling transplanting; the antibiotic treatments were kind of generic antibiotic tetracycline and ampicillin applied in soil at $1 \mathrm{~g} / \mathrm{kg}$. Control treatments received neither Azotobacter nor antibiotic. All treatments were replicated three times.

A total of $1 \mathrm{~kg}$ soil mixed with $50 \mathrm{~g}$ chicken manure was put on $1.5 \mathrm{~L}$ black pot; all soil in pot was saturated with ground water; treated with antibiotic and placed 3 days in the green house. Two weeks-old day rice seedlings were grown on soil saline soil and transferred to potted soil as much as 4 seedlings each. Bacterial inoculation and 50\% of recommended dose nitrogenphosphorus-potassium compound fertilizer were applied at the planting time. Liquid-culture's Azotobacter as much as $10 \mathrm{~mL}$ was diluted by ground water and poured equally surrounding rice seedling; the amount of water was depended on expected final population of exogenous Azotobacter in soil. Inorganic fertilizer was placed $5 \mathrm{~cm}$ below mud soil in two holes. Rice were growing in green house for 9 days.

Soil total nitrogen, Azotobacter population, acidity and EC were measured at 9 days after transplanting. Soil total nitrogen was determined by Kjeldahl method after acid destruction. Population of Azotobacter was count from rice rhizosphere using serial dilution plate method with N-free Ashby's medium. Soil acidity and EC were measured after being diluted with 2.5 part and 5 part of distillated water respectively. All set of data were subjected to analyze of variance with 95\% significance level; and 95\% Duncan's Multiple Range Test whenever the effect of treatment on parameters was significant.

\section{RESULTS AND DISCUSSION}

\subsection{Soil Total Nitrogen and Azotobacter Population}

Analysis of variance showed that the interaction between the Azotobacter and antibiotic treatments on total nitrogen in soil was significant (Table 1). There was no change in $\mathrm{N}$ content when soil was inoculated by $10^{6} \mathrm{CFU} / \mathrm{g}$ and $10^{8} \mathrm{CFU} / \mathrm{g}$ of Azotobacter but $\mathrm{N}$ content in ampicillin-contaminated soil with Azotobacter of $10^{7} \mathrm{CFU} / \mathrm{g}$ was lower than those in soil without antibiotics and in the presence of tetracycline. Azotobacter inoculation and antibiotic contamination didn't show significant interaction effect on Azotobacter population in rice rhizosphere at 9 days; main effect of both treatments didn't influence Azotobacter count (Fig 1) based on variance analysis.

In the beginning of experiment, exogenous Azotobacter in soils were $10^{6}, 10^{7}$, and $10^{8} \mathrm{CFU} / \mathrm{g}$. Azotobacter population in soil before inoculation was $10^{5} \mathrm{CFU} / \mathrm{g}$; those in rice rhizosphere at the end of experiment was $10^{6} \mathrm{CFU} / \mathrm{g}$. The increase of bacterial population in rhizosphere compared to the count before experiment indicated that exogenous Azotobacter colonized the rhizosphere in the presence of high exchangeable sodium $(2.39 \mathrm{cmol} / \mathrm{kg})$ and high EC $(1.8 \mathrm{dS} / \mathrm{m})$ in soil. Exudates released by seedling root induced microbial proliferation in the rhizosphere due to organic substances $[17,18]$. Ability of Azotobacter to whithstand to salinity was reported elsewhere [12,13,14]; in our experiment, Azotobacter K4 was isolated from soil with EC of 8 $\mathrm{dS} / \mathrm{m}$ and can survive in paddy soil which has EC of only $1.8 \mathrm{dS} / \mathrm{m}$. Azotobacter population in 
control treatments, either without Azotobacter or Antibiotic, were statistically similar to those in treated soil which is suggested that the decline of Azotobacter count in soil with initial population of $10^{7}$ and $10^{8} \mathrm{CFU} / \mathrm{g}$ rhizosphere was not caused by the treatments.

Table 1. Interaction effect between Azotobacter soil inoculation and antibiotic on total nitrogen in soil at 9 days after transplanting in saline soil

\begin{tabular}{lccc}
\hline \multirow{2}{*}{ Azotobacter Inoculation $(\mathrm{CFU} / \mathrm{g})$} & \multicolumn{3}{c}{ Soil Total Nitrogen $(\%)$} \\
\cline { 2 - 4 } & Control & Tetracycline & Ampicillin \\
\hline Control (without Azotobacter) & $0.33 \mathrm{a}$ & $0.34 \mathrm{a}$ & $0.28 \mathrm{~b}$ \\
& $\mathrm{~A}$ & $\mathrm{~A}$ & $\mathrm{~A}$ \\
$10^{6}$ (Liquid inoculant) & $0.33 \mathrm{a}$ & $0.27 \mathrm{a}$ & $0.33 \mathrm{~b}$ \\
& $\mathrm{~A}$ & $\mathrm{~A}$ & $\mathrm{~A}$ \\
$10^{7}$ (Liquid inoculant) & $0.32 \mathrm{a}$ & $0.31 \mathrm{a}$ & $0.19 \mathrm{a}$ \\
& $\mathrm{B}$ & $\mathrm{B}$ & $\mathrm{A}$ \\
$10^{8}$ (Liquid inoculant) & $0.24 \mathrm{a}$ & $0.30 \mathrm{a}$ & $0.28 \mathrm{~b}$ \\
& $\mathrm{~A}$ & $\mathrm{~A}$ & $\mathrm{~A}$ \\
\hline
\end{tabular}

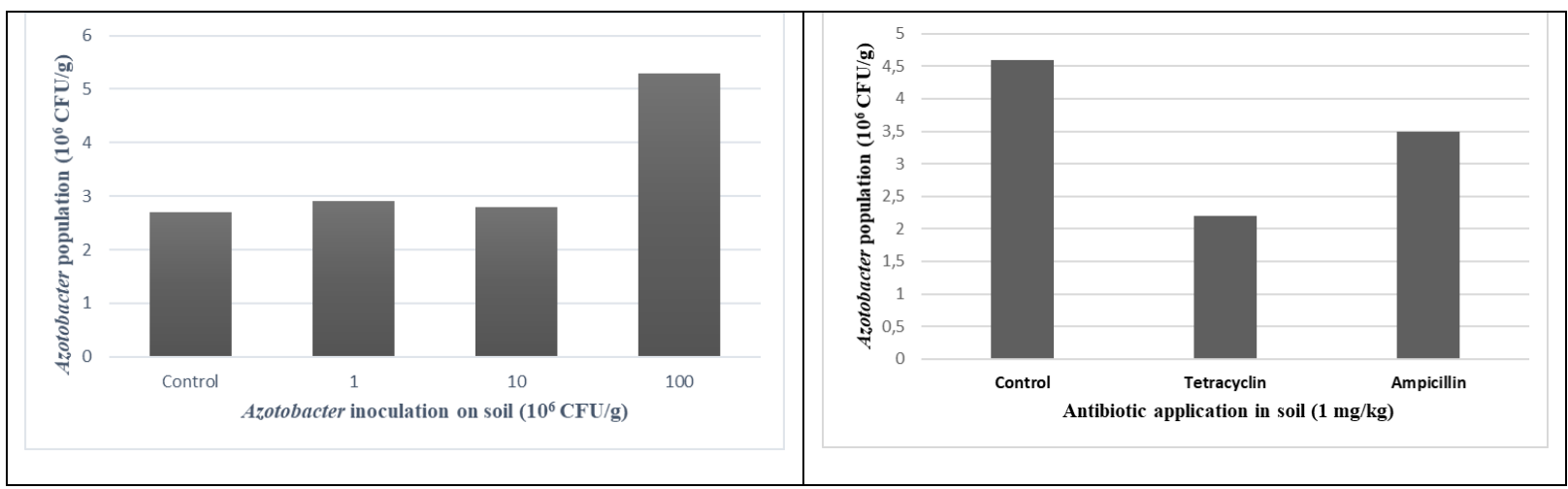

Fig 1. Effect of Azotobacter inoculation (left) and antibiotic (rights) on Azotobacter population in rice seedling rhizosphere in saline soil at 9 days after transplanting

Before experiment, soil total $\mathrm{N}$ was as low as $0.19 \%$ but at the end of experiment, $\mathrm{N}$ content in soil was generally increased up to around $0.3 \%$ (Table 1). Increased in total $\mathrm{N}$ did not due to Azotobacter inoculation but it came from organic matter amendment before planting and urea application since total $\mathrm{N}$ in control treatment did not significantly differ. Free-living $\mathrm{N}$ fixing Azotobacter is a heterotrophic Plant Growth Promoting Rhizobacteria that depend on organic matter for proliferation. Bacteria living in rhizosphere are more functional in transforming nutrients compared to bacteria in bulk soil [19]; root exudation provide organic matter as carbon and nitrogen source as well as terminal electron for their aerobic metabolism. 
Vol. 4, No. 03; 2019

ISSN: $2456-8643$

\subsection{Soil Acidity, Electrical Conductivity and Shoot Heights}

The experiment showed that interaction between Azotobacter and antibiotic treatment did not significantly affect soil acidity, EC as well as shoot heights. Neither Azotobacter nor antibiotic influenced the traits measured (Table 2). Comparing to the soil before experiment, soil acidity did not change but soil EC was increased irrespective of the treatments (Table 2). Soil EC increased from 1.7 dS/m before experiment to 3.1-3.4 after rice grows for only 12 days (Table 2). Rice is sensitive to salt-accumulated soil; they did not survive when soil EC is 2-3 dS/m [20, 21].

Electrical conductivity of clay soil in this experiment was $1.8 \mathrm{dS} / \mathrm{m}$ which measured after fivefold dilution by distillated water; classified soil with EC 1-2 dS/m as high salinity soil [16]. Toxic effect of sodium on plant growth was clearly demonstrated. Plant growth was inhibited and plant leaves showed salt stress symptoms; leaves desiccation, pale green in color, rolling inward and chlorosis were observed in the oldest leaves. At 12 days after transplanting, all rice plants in 11 pot were not survived. We decided to terminate the experiment at 12 days after planting when soil acidity and EC were analyzed. Growth response of upland rice cultivar Inpari34 was in accordance with growth of some rice genotype in solution at $8 \mathrm{dS} / \mathrm{m}$ at 7 days when their fresh and dry weight as well as shoot heights were reduced [22].

Table 2. The effect of Azotobacter inoculation and antibiotic contamination on shoot height at 9 days after transplanting in saline soil, and soil acidity and electrical conductivity at 12 days

\begin{tabular}{lccc}
\hline $\begin{array}{c}\text { Azotobacter inoculation } \\
(\text { CFU/g) }\end{array}$ & Soil Acidity $^{*}$ & EC $(\mathrm{dS} / \mathrm{m})^{*}$ & $\begin{array}{c}\text { Shoot height } \\
(\mathrm{cm})^{*}\end{array}$ \\
\hline Control (Without Azotobacter) & 6.27 & 3.3 & 17.5 \\
$10^{6}$ (Liquid inoculant) & 6.26 & 3.1 & 17.1 \\
$10^{7}$ (Liquid inoculant) & 6.24 & 3.4 & 17.3 \\
$10^{8}$ (Liquid inoculant) & 6.26 & 3.1 & 16.8 \\
\hline Antibiotic (1 mg/kg) & & & \\
Control & 6.17 & 3.4 & 17.2 \\
Tetracycline & 6.29 & 3.2 & 17.3 \\
Ampicillin & 6.31 & 3.2 & 17.0 \\
\hline
\end{tabular}

"Data from three replicates

Damage of rice plant in saline soil in controlled conditions caused by osmotic imbalance and accumulation of chloride ion was reported ([22]. Plant growth inhibition due to excessive sodium $(\mathrm{Na} 2+)$ uptake; causes $\mathrm{Na}$ ions to be absorbed enormously by plants [23]. In saline soils, roots were inhibited to absorb nutrients such as $\mathrm{Ca}^{2+}, \mathrm{K}^{+}, \mathrm{N}$, and $\mathrm{P}$ in soil [24]. Chlorosis in older rice 
leaves was due to low $\mathrm{N}$ uptake and consequently $\mathrm{N}$ from older leaves was mobilized to the young one. Pale color in rice leaves was caused by reduced chlorophyll content since accumulation various salt inhibited biosynthesis of certain chlorophyll fraction [25].

\section{Conclusion}

The effect of Azotobacter K4 concentration inoculated to rice seedling in saline soil on total nitrogen content was depend on type of antibiotic contaminated to the soil. Application of saltresistent Azotobacter up to $10^{6}$ and $10^{8} \mathrm{CFU} / \mathrm{g}$ of maintained nitrogen content in ampicillincontaminated soil but those of $10^{7} \mathrm{CFU} / \mathrm{g}$ lowered total nitrogen. Irrespective of Azotobater and antibiotic treatments, Azotobacter population in the rhizosphere of rice seedling grown in saline soil showed higher bacterial count than those in bulk soil before experiment which is indicated that Azotobacter K4 was tolerant to high sodium as well as EC in soil. Azotobacter inoculation at any level and type of antibiotics didn't affect soil $\mathrm{pH}, \mathrm{EC}$ and plant growth; although Azotobacter was survive in the rice seedling rhizosphere, their activity to perform PGPR effect was not evidence due to high sodium and EC in soil. This reseach suggest that in saline soil, the contribution of antibotic-resistent Azotobacter on rice seedling growth could not be explained properly since high sodium and EC suppressed plant growth.

\section{ACKNOWLEDGEMENT}

The research was funded by Academic Leadership Grant of Universitas Padjadjaran for 2018 Academic year. Authors thank to Soil Research Centre of Indonesian Ministry of Agriculture for Azotobacter's antibiotic resistance test.

\section{REFERENCES}

[1] L. Xiong, K.S. Schumaker, J-K. Zhu, "Cell Signaling during Cold, Drought, and Salt Stress," Plant Cell, 14(Suppl), pp. s165-s183, 2002.

[2] G. Mcclung, W. Frankenberger, "Soil nitrogen transformations as affected by salinity," Soil Science. 139(5), pp. 405-411, 1985.

[3] M. Akhtar, F. Hussain, M.Y. Ashraf, T.M. Qureshi, J. Akhter, A. R. Awan, "Influence of Salinity on Nitrogen Transformations in Soil," Communications in Soil Science and Plant Analysis, 43, pp. 674-1683, 2012.

[4] F. Kusmiyati, E.D. Purbajanti, Surahmanto, "The Effect Of Manure at Saline Soil on Growth, Dry Matter Production and Crude Protein of Sesbania grandiflora," In IOP Conference Series: Earth and Environmental Science, 119, 012023, 2018

[5] C.K. Yost, M.S. Diarra, E. Topp, "Animals and Humans as Sources of Fecal Indicator Bacteria,” pp. 67-92. In The Fecal Bacteria, M.J. Sadowsky and R.L. Whitman (eds), ASM Press, Washington, DC, 2011.

[6] R. Marti, A. Scott, Y-C. Tien, R. Murray, L. Sabourin, Y. Zhang, E. Topp, "Impact of Manure Fertilization on the Abundance of Antibiotic Resistant Bacteria and Frequency of 
Detection of Antibiotic Resistance Genes in Soil and on Vegetables at Harvest," Applied and Environmental Microbiology, 79(18), pp. 5701-5709, 2013.

[7] Q. Yang, H. Zhang,Y. Guo, T. Tian, "Influence of Chicken Manure Fertilization on Antibiotic-Resistant Bacteria in Soil and the Endophytic Bacteria of Pakchoi,". Internatioanl Journal on Environment Research and Public Health. 2016 Jul; 13(7), pp. 662, 2016.

[8] K. Kukreja, S. Suneja, S. Goyal, N. Narula, "Pytohormone Production by Azotobacter-A Review", Agricultural Review, 25 (1), pp. 70 - 75, 2004.

[9] R. Hindersah, W. Perdanawati. Selection of Azotobacter from Dry Land and Its Effect on Maize Seedling, Asian Journal of Science and Technology, 9(11), pp. 8982-8985, 2018.

[10] R.Shrivastava, A.K. Shrivastava, N. Dewangan, "Combined Application of Azotobacter and Urea to Improve Growth of Rice (Oryza sativum)," IOSR Journal of Environmental Science, Toxicology and Food Technology, 1(3), pp. 67-72, 2015.

[11] W.J. Page, S. Shivprasad, "Azotobacter salinestris sp. nov. A Sodium-Dependent, Microaerophilic, and Aeroadaptive Nitrogen-Fixing Bacterium," International Journal of Systematic Bacteriology, 41(3), pp. 369-376, 1991.

[12] M.S. Akhter, S.J. Hossain, S.K.A. Hossain, R. K. Datta, "Isolation and Characterization of Salinity Tolerant Azotobacter sp.," Greener Journal of Biological Sciences, 2(3), pp. 043051, 2012.

[13] J. Bhaduri, P. Kundu, S.E. Kabir, S.K. Roy, "Isolation and Characterisation of Non Symbiotic Nitrogen Fixing Bacteria (Azotobactor Sp.) from Tea Field Soil of Terai Region of North Bengal, India“" International Journal of Advanced Research in Engineering and Applied Sciences, 5(8), pp. 19-33, 2016

[14] S. Paul, C. Bandeppa, J.K Aggarwal, M. Thakur et al., "Effect of Salt on Growth and Plant Growth Promoting Activities of Azotobacter chroococcum Isolated from Saline Soils," Environment and Ecology 32(4), pp.1255-1259, 2014

[15] FAO, "Agricultural Drainage Water Management in Arid and Semi-Arid Areas," Irrigation and Drainage Paper 61, Food and Agriculture Organization of the United Nations, Rome, Italy, 2002.

[16] M. Hardie, R. Doyle, 2012, “Measuring Soil Salinity,” In Plant Salt Tolerance: Methods and Protocols, S. Shabala and T. A. Cuin (eds.), Methods in Molecular Biology, 913, pp. 415425, 2012.

[17] Q. Chaudhry, M. Blom-Zandstra, S. Gupta, E. Joner, "Utilizing The Synergy Between Plants and Rhizosphere Microorganisms to Enhance Breakdown of Organic Pollutants in The Environment," Environment Science and Pollution Research, 12, pp. 34-48, 2005. 
[18] S. Shi, A.E. Richardson, M. O'Callaghan, K.M. DeAngelis et al, "Effects of Selected Root Exudate Components on Soil Bacterial Communities," FEMS Microbiology and Ecology, 77, pp. 600-610, 2011.

[19] R. Hayat, S. Ali, U. Amara, R. Khalid, I. Ahmed, I., "Soil Beneficial Bacteria and Their Role in Plant Growth Promotion: A Review," Annual Microbiology, 60, pp. 579-598, 2010.

[20] M.L. McFarland, T.L. Provin, L.A, Redmon, D.E. Boellstroff et al., "An Index of Salinity and Boron Tolerance of Common Native and Introduced Plant Species in Texas," Texas A\&M AgriLife Extension Service, College Station, Texas, USA, 2014

[21] T.M.L. Hoang, T.N. Tran, T.K.N. Nguyen, B. Williams, P. Wurm, S. Bellairs, S Mundree, "Improvement of Salinity Stress Tolerance in Rice Challenges and Opportunities," Agronomy, 6, 54, 23 p, 2016.

[22] F. Gholizadeh, S. Navabpour, "Effect of Salinity on Morpological and Physiological Characteristics in Correlation to Selection of Salt Tolerance in Rice (Oryza sativa L.)," International Journal of Agricultural Research, 6(11), pp. 708-788, 2011.

[23] J. Acosta-Motos, M. Ortuño, A. Bernal-Vicente, P. Diaz-Vivancos, M. Sanchez-Blanco, J. Hernandez, "Plant Responses to Salt Stress: Adaptive Mechanisms," Agronomy, 7,18, 38 p, 2017.

[24] M. Tejada, C. Garcia, J.L. Gonzalez, M.T. Hernandez, "Use of Organic Amendment as A Strategy for Saline Soil Remediation: Influence on The Physical, Chemical and Biological Properties of Soil," Soil Biology and Biochemistry, 38, pp. 1413-1421, 2006.

[25] Y. Ali, Z. Aslam, M.Y. Ashraf, G.R. Tahir, "Effect of Salinity on Chlorophyll Concentration, Leaf Area, Yield and Yield Components of Rice Genotypes Grown Under Saline Environment," International Journal of Environmental Science \& Technology 1(3), pp. 221-225, 2004. 